University of Massachusetts Amherst

ScholarWorks@UMass Amherst

\title{
A Model for Evidence-Based Elementary School Counseling: Using School Data, Research, and Evaluation to Enhance Practice
}

\author{
Carey Dimmitt \\ University of Massachusetts Amherst, cdimmitt@educ.umass.edu \\ John Carey \\ University of Massachusetts Amherst
}

Follow this and additional works at: https://scholarworks.umass.edu/cscore_pubs

Dimmitt, Carey and Carey, John, "A Model for Evidence-Based Elementary School Counseling: Using School Data, Research, and Evaluation to Enhance Practice" (2008). The Elementary School Journal. 1. https://doi.org/10.1086/589471

This Article is brought to you for free and open access by the CSCORE: Ronald H. Fredrickson Center for School Counseling Outcome Research \& Evaluation at ScholarWorks@UMass Amherst. It has been accepted for inclusion in Peer-Reviewed Publications by an authorized administrator of ScholarWorks@UMass Amherst. For more information, please contact scholarworks@library.umass.edu. 


\section{A Model for Evidence- Based Elementary School Counseling: Using School Data, Research, and Evaluation to Enhance Practice}

\author{
John Carey \\ Carey Dimmitt \\ University of Massachusetts
}

The Elementary School Journal

Volume 108, Number 5

(C) 2008 by The University of Chicago. All rights reserved 0013-5984/2008/10805-0006\$10.00

\begin{abstract}
In this article we present a model for evidencebased school counseling practice that involves using data to specify problems that need addressing, using multidisciplinary teams to identify and implement research-based interventions, and evaluating interventions and programs to demonstrate effects. Potential benefits of this approach for elementary school counselors include interventions with better outcomes for students and enhanced professional standing.
\end{abstract}

School counselors have always worked to provide students with the most effective interventions possible. In the past several years, the school counseling profession has been undergoing a transformation that parallels developments in public education (American School Counselors Association [ASCA], 2003; Bemak, 2000; Martin, 2002). The two major and interrelated reform movements affecting public education are the standards-based and evidence-based practice movements (Elmore, 2003; McDonnell, 2004). The standards-based movement has increased the use of data in the management of public schools and state educational systems. The evidence-based practices movement has increased the use of research-based interventions and the evaluation of school-based interventions. Both of these movements are reflected in the No Child Left Behind Act (U.S. Department of Education, 2004), which requires the use of research-based education practices and quantitative test data to monitor schools' performance.

The school counseling profession is making expeditious advances to keep pace 
with the profound changes occurring in public education. The ASCA national model for school counseling programs (ASCA, 2003) connects school counseling with standards-based educational reform and strategically positions counseling programs in schools through the incorporation of data-based program management and accountability practices. The model emphasizes using data to improve practice and document outcomes. Data use includes a wide range of activities such as analyzing institutional data to identify problems, gathering needs-assessment data to determine constituencies' perceived needs, evaluating the effect of interventions using pre/posttest designs, and documenting the outcomes of school counseling activities and interventions for key stakeholders such as principals, community members, and school boards. Although the ASCA national model incorporates the essential components of standards-based education, we believe there is an additional need for identification and use of research-based interventions and practices in the field.

The main purposes of this article are the following: (a) to outline a model of evidence-based practice for elementary school counseling, $(b)$ to describe how to use data to identify which problems are most critical for a school counseling program to address, (c) to explain ways to identify and implement research-based counseling interventions and practices, and (d) to integrate intervention and program evaluation into practice.

\section{What Is Evidence-Based Practice?}

The evidence-based practice movement originally evolved in the field of medicine and has been defined as "the integration of the best evidence with clinical expertise and patient values" (Sackett, Straus, Richardson, Rosenberg, \& Haynes, 2000, p. 1). This approach emphasizes a medical practitioner's use of the best available research to guide practice and has resulted in signif- icant changes in medical education, which must now include preparing practitioners to use research literature to guide practice. In recent years, many human service professions have incorporated evidence-based principles in both professional practice and education. For example, evidence-based practice concepts are being applied in counseling psychology (Chwalisz, 2003), school psychology (Kratochwill \& Shernoff, 2003), nursing (Deaton, 2001), and public health (Brownson, Gurney, \& Land, 1999).

Sexton, Schofield, and Whiston (1997) argued that adopting an evidence-based practice approach would help the school counseling profession become better integrated by grounding training and practice in the evolving knowledge base of the profession. When what people do is not clearly linked to what is known about what works, there is no certainty that counselors are improving student outcomes as much as possible. Research, particularly outcome studies (which measure changes that occur for those who receive an intervention), can be used to help ensure that professional activities reflect what is known about effective practices and interventions. We believe that a model for evidence-based school counseling is needed to fulfill the promise of the approach that Sexton et al. (1997) noted.

\section{A Model for Evidence-Based School Counseling Practice}

Based on Shlonsky and Gibbs's (2004) conceptualization of evidence-based practice for helping professions, we have developed the following model (see Fig. 1). This model of evidence-based school counseling practice suggests that counselors (a) use data to identify and describe a problem that needs to be addressed (i.e., problem description), (b) find interventions or practices that have been shown to lead to improvement in this problem area (i.e., outcome research use), and (c) determine whether the implemented interventions or practices were effective (i.e., intervention evaluation) (Dim- 


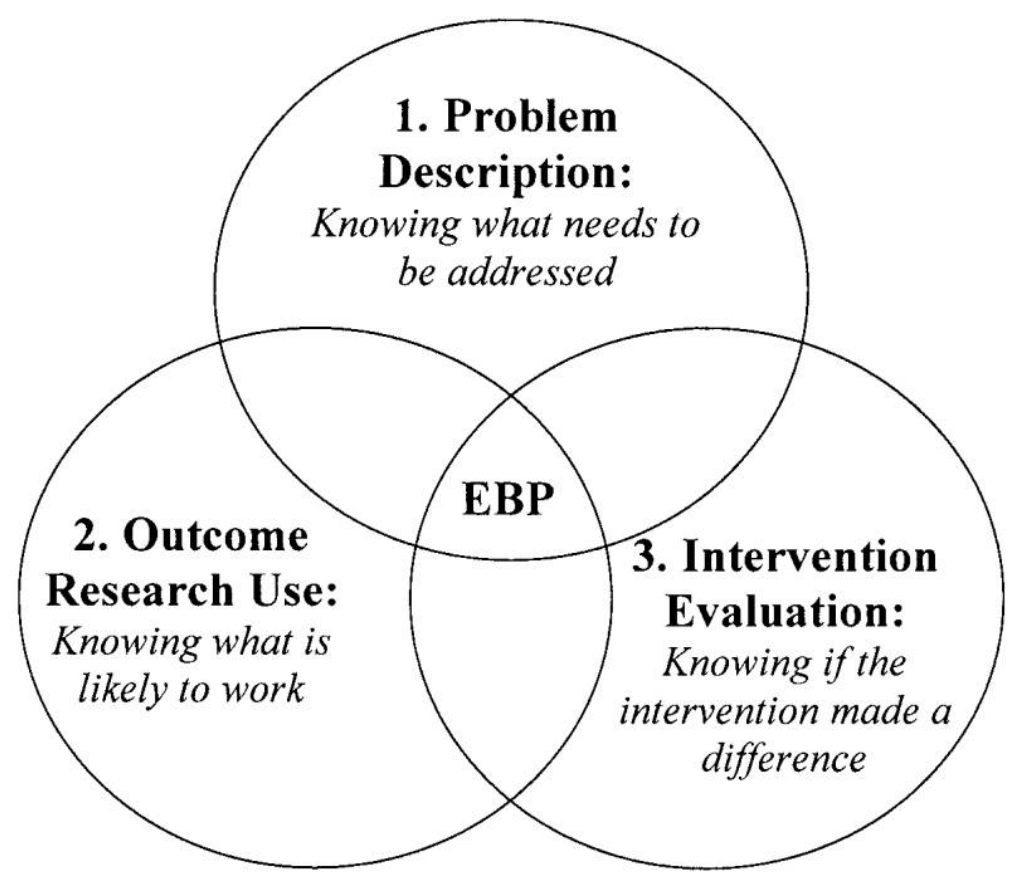

FIG. 1.-A model of evidence-based practice (EBP) for school counseling

mitt, Carey, \& Hatch, 2007). Any one of these components can be considered evidence-based practice, but when school counselors are doing all three, it is more likely that the most significant problems in a school are being addressed with the best possible intervention(s) and that students are benefiting from the school counseling program. Additionally, although the model can be used sequentially, counselors can use it to evaluate existing interventions or to select research-based interventions to address problems they have already identified.

\section{Knowing What Problem Needs to Be Addressed}

Problem description is accomplished by using institutional data about student performance and behavior to identify problems that need to be addressed. This process is often referred to as data-based decision making. An elementary school counselor, for example, would want to collect data on the frequency and nature of disciplinary referrals related to fighting and bullying before deciding whether or not a violenceprevention intervention was necessary. A request from a teacher, parent, or administrator can be sufficient to initiate investigation of a problem, but to be using evidencebased practice, counselors need to have data showing that a problem exists before implementing an intervention to address it.

Several excellent models of educational data-based decision making exist. Some models are whole school (Johnson, 2002; Love, 2002), whereas others are designed to address particular school counseling program components such as evaluation and accountability (Dahir \& Stone, 2003; Isaacs, 2003). Reynolds and Hines (2000) suggest that counselors use data-based decision making to initiate school reform efforts focused on achievement-gap remediation. In this model, a school counselor leads an interdisciplinary team that defines problems and decides on interventions. All of these 
models focus on the use of data to define problems, set goals, and target interventions. Many models also include steps related to evaluation and accountability.

\section{Knowing What Is Likely to Work}

Research-based interventions are identified by reviewing relevant outcome research literature and deciding what interventions can be implemented in a particular school. Before implementing a specific bullyingprevention program, for example, a counselor would need to determine that a program has been shown to reduce targeted behaviors and that the format and time requirements of the program were compatible with school schedules and routines. It is helpful for school counselors to be able to access information about research-based practices, lead or participate in teams to identify effective interventions, and evaluate the feasibility of implementing interventions in a manner similar to the way they were implemented in outcome studies.

\section{Why Are Research-Based Elementary School Counseling Interventions Important?}

The effectiveness of research-based interventions has been supported by highquality outcome research. Such research establishes a causal link between an intervention and changes in student behavior, knowledge, and/or skills. For example, outcome research will determine whether a program such as Student Success Skills (Brigman \& Campbell, 2003) results in changes in students' standardized test performance, use of self-management techniques, and academic self-efficacy. Typical outcome studies require that a group that experienced an intervention (the experimental group) be compared with at least one group that did not (the control or comparison group). If the groups are equivalent on the outcome variables of interest prior to an intervention, and differences between the two groups are found, there is some evidence that the intervention affected the outcome.

Using research-based interventions can generally ensure that school counseling resources are invested wisely. Every decision to use time and material resources in one way precludes the use of those resources in other ways. Counselors must choose among alternative ways to accomplish the same outcomes. For example, will using the Second Step Violence Prevention Curriculum (Committee for Children, 2006) or developing a peer-mediation program benefit students more? Second Step has strong research support (Carey, Dimmitt, Hatch, Lapan, \& Whiston, in press; Grossman et al., 1997); however, many elementary interventions currently lack such support. It is not that these interventions are ineffective; rather, there is not yet evidence proving that they are effective. Usually counselors must choose between interventions known to be effective and those that may be effective but have not yet been evaluated.

Historically in education, factors other than research support (professional wisdom, tradition, theory) have been salient in decisions about interventions (U.S. Department of Education, 2002). Counselors may prefer to use materials they have developed themselves (e.g., lesson plans) rather than commercially available materials because of the perception that the former are less expensive. A true cost-benefit analysis of an intervention, however, would include how much time it took the counselor to create materials. Although both the cost and expected benefits of research-based interventions are known, counselor-generated interventions may actually cost more than expected, and their outcomes are unknown. Thus it makes sense to develop curriculum only when no relevant researchbased intervention exists, or when the needs of the students being served are so specific that a research-based intervention cannot be implemented (e.g., special needs, cognitive capacity, etc.). Often, modifica- 
tion of existing curriculum materials is still preferable to developing new ones.

Sometimes the choice of intervention is also influenced by testimonial endorsement and packaging. Professional meetings may feature sessions about "practices that work," with an engaging demonstration of an intervention, and conferences have exhibit halls where vendors promote and sell materials with attractive packaging. These marketing strategies can influence what a counselor uses when, in fact, the most important issue is whether there is research evidence that an intervention is effective. Often, there is not.

Using research-based interventions sets a standard for professional practice. One hallmark of a profession is that its practice is based on a scientifically tested body of knowledge as well as on consensually validated opinions about what is effective. To date, school counseling (like other education professions) has relied on a knowledge base driven more by theory and collective practitioner experience than by research on what works for students. Both counselor education and practice would benefit from greater use of the research base about effective practice (Sexton et al., 1997). We believe that basing practice on the evolving outcome research literature will enhance the professional status of school counseling by increasing confidence that counselors implement only interventions that have been proven effective.

\section{Knowing If an Intervention Made a Difference}

Evaluation provides information about whether or not an intervention or program is working. The use of evaluation to provide documentation of the effectiveness of a school counseling program to local educational decision makers (district administrators, school boards, principals) has long been accepted as a necessary and important professional activity (Keene \& Stewart, 1989). Knowing that an intervention is sup- ported by sound outcome research does not assure that it will have the desired effect in all settings, and it is necessary to evaluate the effects of the intervention in the counselor's setting. Evaluation serves both program improvement and accountability purposes by providing information about whether or not a program is effective enough to be continued and by documenting outcomes of school counseling interventions.

Quality accountability data are easier to generate when counselors use researchbased interventions. It is easier to document effectiveness when an intervention's utility in other settings has been shown because evaluation materials may already exist, the outcomes affected have been identified, and there is a greater likelihood that a counselor can replicate the outcomes for which research evidence already exists.

\section{Developing Evidence-Based Practice Teams}

Locating interventions that will work in a school is best done as a team enterprise. In elementary schools, this typically involves the establishment of an evidence-based practice team (EBPT) led by the school counselor, with other members drawn from school professionals who should be involved with solving the presenting problem. Teams usually come into existence when a difficulty is identified, for example, stress management during high-stakes testing. Although school administrators may not have identified a problem initially, their endorsement of and support for the work of the team need to be in place and be communicated broadly across the school. The work of the EBPT matches the evidence-based practice model we have proposed. The EBPT (a) defines the problem (using data where possible), (b) identifies interventions and approaches that are both research based and feasible and recommends interventions to the administration and school community, and (c) develops an 
TABLE 1. Information Sources on Research-Based Practices

\begin{tabular}{|c|c|c|}
\hline Source & Types of Interventions Evaluated & Web Address \\
\hline What Works Clearing House & $\begin{array}{l}\text { Wide range of interventions } \\
\text { including Character Education }\end{array}$ & http://www.whatworks.ed.gov/ \\
\hline $\begin{array}{l}\text { National Center for Chronic } \\
\text { Disease Prevention and } \\
\text { Health Promotion }\end{array}$ & $\begin{array}{l}\text { School-based prevention/health } \\
\text { promotion interventions }\end{array}$ & http://www.cdc.gov / HealthyYouth/ \\
\hline $\begin{array}{l}\text { U.S. Department of } \\
\text { Education's Office of Safe } \\
\text { and Drug-Free Schools }\end{array}$ & $\begin{array}{l}\text { Programs that promote safe and } \\
\text { drug-free schools }\end{array}$ & $\begin{array}{l}\text { http://www.ed.gov/about/offices/list/ } \\
\text { osdfs/index.html }\end{array}$ \\
\hline $\begin{array}{l}\text { Substance Abuse and Mental } \\
\text { Health Services } \\
\text { Administration's National } \\
\text { Registry of Evidence-Based } \\
\text { Programs and Practices }\end{array}$ & $\begin{array}{l}\text { Wide range of programs related } \\
\text { to substance abuse prevention } \\
\text { and mental health promotion }\end{array}$ & http://modelprograms.samhsa.gov/ \\
\hline $\begin{array}{l}\text { Collaborative for Academic, } \\
\text { Social, and Emotional } \\
\text { Learning }\end{array}$ & $\begin{array}{l}\text { Programs that enhance academic } \\
\text { achievement through } \\
\text { personal/social interventions }\end{array}$ & http://www.casel.org \\
\hline $\begin{array}{l}\text { Center for School Counseling } \\
\text { Outcome Research }\end{array}$ & $\begin{array}{l}\text { Evidence-based school } \\
\text { counseling information }\end{array}$ & www.cscor.org \\
\hline
\end{tabular}

implementation evaluation plan to guide implementation and determine whether the selected interventions are working.

\section{Defining the Problem}

It is often necessary for an EBPT to spend some time defining the problem they are addressing, because most problems result from multiple causes. For example, one team that was charged with finding out how to improve fourth-grade English language arts test scores discovered that many students who failed the test spoke two languages but were no longer receiving English language learner services. Implementing interventions without taking this information into consideration would not have significantly improved test scores. Thus, teams should not select interventions until they know what is causing a problem. Analyzing school data or gathering additional data about groups of children may be necessary to achieve this end.

\section{Identifying Interventions and \\ Approaches}

EBPTs can locate research-based interventions in several ways. A number of professional panels and organizations evaluate the outcome research base and distribute findings through websites and print media. The National Panel for School Counseling Evidence-Based Practice has developed criteria for assessing high-quality school counseling outcome research and continuously identifies research-based school counseling interventions (Carey \& Dimmitt, 2006). The panel disseminates its findings both online (http://www.cscor.org) and in print (see Carey et al., in press). Additional sources of information on research-based practices are contained in Table 1. Finally, EBPTs can consult research briefs prepared and distributed by the National Center for School Counseling Outcome Research (http://www.cscor.org). In addition to school counseling research, the areas of health education, career counseling, special education, school psychology, social work, and group counseling all may have research relevant to school-based interventions. For example, reviews of research on group counseling with children (Hoag \& Burlingame, 1997), school-based career education (Baker \& Taylor, 1998; Evans \& Burck, 1992), psychotherapy outcomes (Whiston \& Sexton, 1993), and school-based programs designed to reduce aggression (Wilson, Lipsey, \& Derzon, 
2003) would be helpful for elementary EBPTs. These reviews can be found through standard library research and increasingly through online search engines such as Google Scholar (http://scholar. google.com/).

Using the abovementioned sources, an EBPT can often compile a descriptive list of research-based interventions that are appropriate for a specific problem and student population. Next this list needs to be evaluated for feasibility. The basic question to be asked at this point is, can the intervention be implemented in our school with fidelity? The team needs to take into account pragmatic considerations such as cost, time required, fit with existing interventions and approaches, training requirements, compatibility with the school's philosophy and values, and compatibility with parents' values and sensibilities. Ultimately, the intervention must be implemented within existing school structures and routines and will require the enthusiastic support of administrators, teachers, and parents. Based on a feasibility analysis, the EBPT should narrow the list of possible research-based interventions to three or fewer that can be recommended to administrators and the school community.

It is essential that the principal and other school administrators be actively involved in this phase of the process because they are entrusted with the responsibility of ensuring that school resources are invested in ways that enhance student learning. It is also important to present the analysis and recommendations of the EBPT to the school staff, who will need to be involved in order to ensure successful implementation. The EBPT should be prepared to review the problem being addressed, the research support for each recommended intervention, the team analysis of feasibility issues for each intervention, and the expectations of school staff regarding their responsibilities in preparing for, implementing, and evaluating the interventions. Feedback from colleagues can provide the team with valuable information about possible challenges to and potential leaders in the intervention process. It is also wise to make a truncated presentation to a representative parent group to identify any potential concerns.

Developing the Implementation and Evaluation Plan

After the decision about interventions is made, the EBPT needs to develop an implementation action plan and an evaluation plan. Implementation plans include task assignments with time lines and responsible parties identified for each task. The evaluation plan includes information on both the formative evaluation (i.e., how the team will know the intervention is being implemented properly) and summative evaluation (i.e., how the team will know whether the intervention has the desired effect). In evaluating an intervention, it is necessary to determine whether the desired behavior and performance changes occurred as a result of the application of the intervention. It is important for the team to identify desired student outcomes such as what behaviors they are trying to change (e.g., social skills, attendance, test scores, etc.) and the evidence that the interventions contributed to any changes found.

If a program component is having the desired effects on students, it can then be continued. If the outcome measures fail to show the effects hoped for, the intervention may not be effective, the measurement may be inappropriate for determining outcomes, or the wrong outcomes may have been measured.

\section{Summary}

By moving to an evidence-based practice model, elementary school counselors can achieve greater improvement in student learning and development and enhance their professional practice. Operating from an evidence-based practice perspective means that counselors use evidence to define problems, select effective interven- 
tions, and determine whether interventions are effective when implemented at a school. School counselor-led evidence-based practice teams are an efficient and effective way to (a) identify research-based interventions, (b) determine which research-based interventions are best for the school in which they will be implemented, and (c) organize successful implementation and evaluation of researchbased interventions. When counselors use an evidence-based practice approach, they can know with greater certainty that they are providing the most effective services possible for students.

\section{References}

American School Counselors Association. (2003). The ASCA National Model: A framework for school counseling programs. Alexandria, VA: Author.

Baker, S. B., \& Taylor, J. G. (1998). Effects of career education interventions: A metaanalysis. Career Development Ouarterlu, 46, 376-385.

Bemak, F. (2000). Transforming the role of the counselor to provide leadership in educational reform through collaboration. Professional School Counseling, 3, 323-331.

Brigman, G., \& Campbell, C. (2003). Helping students improve academic achievement and school success behavior. Professional School Counseling, 7, 91-98.

Brownson, R. C., Gurney, J. G., \& Land, G. H. (1999). Evidence-based decision making in public health. Journal of Public Health Management, 5, 86-97.

Carey, J. C., \& Dimmitt, C. (2006). Resources for school counselors and counselor educators: The National Center for School Counseling Outcome Research. Professional School Counseling, 9, 416-420.

Carey, J. C., Dimmitt, C., Hatch, T. A., Lapan, R. T., \& Whiston, S. C. (in press). Report of the National Panel for Evidence-Based School Counseling: Outcome Research Coding Protocol and Evaluation of Student Success Skills and Second Step. Professional School Counseling.

Chwalisz, K. (2003). Evidence-based practice: A framework for twenty-first-century scientistpractitioner training. Counseling Psuchologist, 31, 497-528
Committee for Children. (2006). Second step: A violence prevention curriculum [On-line]. Available: http://www.cfchildren.org/cfc/ ssf/ssf/ssindex/

Dahir, C. A., \& Stone, C. B. (2003). Accountability: A M.E.A.S.U.R.E. of the impact school counselors have on student achievement. Professional School Counseling, 6, 214-221.

Deaton, C. (2001). Outcomes measurement and evidence-based nursing practice. Iournal of Cardiovascular Nursing, 15, 83-86.

Dimmitt, C., Carey, J., \& Hatch, T. (2007). Evidence-based school counseling: Making a difference with data-driven practices. Thousand Oaks, CA: Corwin.

Elmore, R. (2003). Accountability and capacity. In M. Carnoy, R. Elmore, \& L. S. Siskin (Eds.), The new accountability: High schools and high-stakes testing (pp. 195-209). New York: RoutledgeFalmer.

Evans, J. H., \& Burck, H. (1992). The effects of career education interventions on academic achievement: A meta-analysis. Iournal of Counseling and Development, 71, 63-68.

Grossman, D. C., Neckerman, H. J., Koepsell, T. D., Liu, P., Asher, K. N., Beland, K., Frey, K., \& Rivara, F. P. (1997). Effectiveness of a violence prevention curriculum among children in elementary school. Iournal of the American Medical Association, 227(20), 16051611.

Hoag, M. J., \& Burlingame, G. M. (1997). Evaluating the effectiveness of child and adolescent group treatment: A meta-analytic review. Iournal of Clinical Child Psycholoou, 26, 234-246.

Isaacs, M. L. (2003). Data-driven decision making: The engine of accountability. Professional School Counseling, 6, 288-295.

Johnson, R. S. (2002). Using data to close the achievement gap: How to measure equity in our schools. Thousand Oaks, CA: Corwin.

Keene, K. M., \& Stewart, N. R. (1989). Evaluation: Rx for counseling program growth. The School Counselor, 37, 62-66.

Kratochwill, T. R., \& Shernoff, E. S. (2003). Evidence-based practice: Promoting evidencebased interventions. School Psucholooy Ouarterlu, 18, 389-408.

Love, N. (2002). Using data/getting results: A practical guide for school improvement in mathemat$i c s$ and science. Norwood, MA: ChristopherGordon.

Martin, P. A. (2002). Transforming school counseling: A national perspective. Theory into Practice, 41, 148-153. 
McDonnell, L. (2004). Politics, persuasion, and educational testing. Cambridge, MA: Harvard University Press.

Reynolds, S., \& Hines, P. L. (2000). The Indiana student achievement institute: Guidance-centered whole school reform [On-line]. Available: http:// asai.indstate.edu/ASAI-Documents.htm

Sackett, D. L., Straus, S. E., Richardson, W. S., Rosenberg, W., \& Haynes, R. B. (2000). Evidence-based medicine; How to practice and teach EBM (2d ed.). Edinburgh: Churchill Livingstone.

Sexton, T. L., Schofield, T. L., \& Whiston, S. C. (1997). Evidence-based practice: A pragmatic model to unify counseling. Counseling and $\mathrm{Hu}-$ man Development, 30(4). Denver: Love.

Shlonsky, A., \& Gibbs, L. (2004). Will the real evidence-based practice please stand up? Teaching the process of evidence-based practice to the helping professions. Brief Treatment and Crisis Intervention, 4, 137-153.
U.S. Department of Education. (2002). U.S. Department of Education 2002-2003 annual plan [Online]. Available: http://www.ed.gov/about/ reports/annual/2003plan/annualplan2003. pdf

U.S. Department of Education. (2004). No Child Left Behind [On-line]. Available: http:// www.ed.gov/nclb/landing.jhtml? src $=\mathrm{pb}$

Whiston, S., \& Sexton, T. (1993). An overview of psychotherapy outcome research: Implications for practice. Professional Psychology: Research and Practice, 24(1), 43-51.

Whiston, S. C., \& Sexton, T. L. (1998). A review of school counseling outcome research: Implications for practice. Iournal of Counseling and Development, 76, 412-426.

Wilson, S. J., Lipsey, M. W., \& Derzon, J. H. (2003). The effects of school-based intervention programs on aggressive behavior: A meta-analysis. Iournal of Consulting and Clinical Psychologu, 71, 136-149. 